\title{
Strategies for Prevention of COVID-19 Transmission in Hospitals: a Nationwide Survey of Controversial Issues Related to Infection Control and Prevention in Korea
}

\section{Wooyoung Jang}

Hanyang University College of Medicine

\section{Bongyoung Kim}

Hanyang University College of Medicine

\section{Eu Suk Kim}

Seoul National University Bundang Hospital

\section{Kyoung-Ho Song}

Seoul National University Bundang Hospital

\section{Song Mi Moon}

Hallym University Sacred Heart Hospital

\section{Myung Jin Lee}

Inje University Sanggye Paik Hospital

Ji Young Park

Chung Ang University Hospital

\section{Ji-Yeon Kim}

Seongnam Citizens Medical Center

\section{Myoung Jin Shin}

Seoul National University Bundang Hospital

\section{Hyunju Lee}

Seoul National University Bundang Hospital

Hong Bin Kim ( $\nabla$ hbkimmd@snu.ac.kr)

Seoul National University Bundang Hospital https://orcid.org/0000-0001-6262-372X

\section{Research Article}

Keywords: Coronavirus disease 2019, Hospital, Infection control, Nationwide survey, South Korea

Posted Date: January 6th, 2022

DOI: https://doi.org/10.21203/rs.3.rs-1209219/v1 
License: (c) (i) This work is licensed under a Creative Commons Attribution 4.0 International License. Read Full License 


\section{Abstract}

Background: Infection-control measures against the coronavirus disease 2019 (COVID-19) within a hospital are often based on expert experience and intuition due to the lack of clear guidelines. This study aimed to survey the current strategies for the prevention of the spread of COVID-19 in medical institutions.

Methods: In a systematic review of national-level guidelines, 13 key topics were selected. Six hospitals were provided an open survey between August 11 and 25, 2020, to assess their responses to these topics. Using these data, an online questionnaire was developed and sent to the infection-control teams of 46 hospitals in South Korea. The survey was conducted between January 31, 2021, and February 20, 2021.

Results: All 46 hospitals responded to the survey. All hospitals operated screening clinics, while $89.1 \%$ (41/46) allowed symptomatic patients without COVID-19-associated symptoms to visit the general outpatient clinics. Most hospitals $(87.2 \% ; 34 / 39)$ conducted polymerase chain reaction (PCR) tests for all hospitalised patients. Moreover, 35 (76.1\%) hospitals had preemptive isolation policies for hospitalised patients, of which $97.1 \%(34 / 35)$ released patients from isolation after a single negative PCR test. Most hospitals $(76.9 \% ; 20 / 26)$ allowed shared-room accommodation for patients who met the national criteria for release from isolation but showed positive PCR results with cycle threshold values above a certain threshold $(34.6 \% ; 9 / 26)$ or after a certain period that satisfied the national criteria $(26.9 \% ; 7 / 26)$.

Conclusions: Various guidelines were being applied by each medical institution, but an explicit set of national guidelines to support these guidelines was unavailable.

\section{Background}

Coronavirus disease 19 (COVID-19) is an emerging infectious disease caused by severe acute respiratory syndrome coronavirus 2 (SARS-CoV-2) that was first identified in Wuhan, Hubei Province, China, in December 2019 [1]. Subsequently, it spread rapidly worldwide, and the World Health Organization (WHO) declared a global pandemic on March 11, 2020 [2]. The increasing numbers of serious outbreaks of COVID-19 and confirmed cases in communities have increased the risk of COVID-19 infection in medical institutions. Indeed, several COVID-19 outbreaks have been identified in various medical institutions over the past two years [3].

Since elderly patients with underlying comorbidities are mainly hospitalised for appropriate care, a COVID-19 outbreak in a hospital can result in a high mortality rate [4]. Although strict infection-control measures to prevent nosocomial COVID-19 infections are crucial, the development of appropriate and specific strategies for hospital settings is also important to account for the heterogeneity of the population in hospitals, which includes inpatients, healthcare workers, and outpatients, caregivers, and other professionals. Furthermore, the infrastructure and systems of individual hospitals vary, and the existing guidelines do not address every specific detail [5]. Thus, COVID-19 infection-control measures 
implemented by hospitals often rely on the experience of in-house experts and are often benchmarked against other hospitals' strategies [6].

In the light of these issues, the present study aimed to evaluate the strategies for preventing the inflow of undetected COVID-19 patients into hospitals, preventing infections among healthcare workers when treating suspected or confirmed COVID-19 patients, and preventing the spread of COVID-19 infection in medical institutions by medical personnel. Through this study, we aimed to derive the optimal strategies to prevent the spread of COVID-19 within medical institutions.

\section{Methods}

\section{Questionnaire design}

In the initial phase of questionnaire development, controversial issues related to the prevention of COVID19 transmission within medical institutions were selected via discussion among four infectious diseases (ID) specialists (B.K., E.S.K., K.H.S., and H.B.K.) (Supplement 1). To extract the critical questions related to these issues that are relevant in an actual hospital setting, a systematic literature review of the recommendations and guidelines issued by World Health Organization (WHO), Centers for Disease Control and Prevention (CDC), European Centre for Disease Prevention and Control (ECDC), and Korea Disease Control and Prevention Agency (KDCA) between January 1, 2020, and September 30, 2020, was conducted by two researchers (W.J. and B.K.) (Supplement 2). In addition, we obtained information about real-world practices related to these issues from six ID specialists working at different hospitals by sending an e-mail with a questionnaire consisting of open questions (Supplement 3). Based on a review of the guidelines and information about real-world practices, a questionnaire consisting of closed questions was developed through discussions among investigators in this study (W.J., B.K., E.S.K., K.H.S., S.M.M., M.J.L., J.Y.P., J.Y.K., M.J.S., and H.B.K.) (Supplement 4). The developed questionnaire was refined on the SurveyMonkey ${ }^{\circledR}$ platform (Supplementary Fig. 1).

\section{Conducting the survey}

The survey was conducted over a period of 21 days (from January 31, 2021, to February 20, 2021), targeting the six hospitals where information about real-world practices for controversial topics was gathered and 40 sample hospitals in Korea that were managing COVID-19 patients at the time of the survey. The 40 sample hospitals were selected to account for four categories of hospitals: hospitals operating state-designated isolation beds, hospitals with 500 beds or more that did not operate statedesignated isolation beds, hospitals with less than 500 beds, and hospitals without ID specialists. Ten hospitals of each category were selected while maintaining uniform distributions across regions.

A link to the online-based survey was forwarded via e-mail to the physicians or nurses who belonged to the infection-control teams of each hospital. To encourage participation, reminders were sent on the 5th, 10th, and 15th days. Only one questionnaire was administered per hospital.

\section{Statistical analysis}


To evaluate the differences in strategy according to the experience of managing COVID-19 patients, we compared hospitals that managed 100 or more cases of COVID-19 (COVID-19 $\geq 100$ group) with hospitals that had treated fewer than 100 cases of COVID-19 (COVID-19<100 group). All statistical analyses were performed using SPSS version 24.0 for Windows (IBM Corporation, Armonk, NY, USA). Categorical variables were analysed by the Chi-squared test or Fisher's exact test. Continuous variables were analysed using the Mann-Whitney U-test or independent t-test. Variables with $P$ values $<0.05$ were considered statistically significant.

\section{Results}

\section{Basic information of medical institutions}

Table 1 provides the basic information of the participating medical institutions. All 46 hospitals that were sent the questionnaire responded to the survey. Among them, 24 hospitals had treated 100 or more cases of COVID-19. The majority of hospitals in the COVID-19 < 100 group were private university-affiliated hospitals, while the majority of those in the COVID-19 $\geq 100$ group were public non-university-affiliated hospitals. The proportion of hospitals without an ID specialist was significantly higher in the COVID-19 $\geq$ 100 group than in the COVID-19 $<100$ group $(P=0.011)$. 
Table 1

Basic information on survey respondents and medical institutions

\begin{tabular}{|c|c|c|c|c|}
\hline & $\begin{array}{l}\text { Total } \\
(n= \\
46)\end{array}$ & $\begin{array}{l}\text { No. of COVID-19 } \\
\text { cases }<100 \\
(n=22)\end{array}$ & $\begin{array}{l}\text { No. of COVID-19 } \\
\text { cases } \geq 100 \\
(n=24)\end{array}$ & $\begin{array}{l}P \\
\text { value }\end{array}$ \\
\hline \multicolumn{5}{|l|}{ Characteristics of respondents } \\
\hline Age & $\begin{array}{l}44 \\
(38- \\
50)\end{array}$ & $41(37.75-49)$ & $45.5(39.25-50)$ & 0.257 \\
\hline Female & $\begin{array}{l}29 \\
(63.0)\end{array}$ & $13(59.1)$ & $16(66.7)$ & 0.595 \\
\hline \multicolumn{5}{|l|}{ Classification } \\
\hline Infection control doctor & $\begin{array}{l}41 \\
(89.1)\end{array}$ & $21(95.5)$ & $20(83.3)$ & 0.349 \\
\hline Infection control nurse & $\begin{array}{l}5 \\
(10.9)\end{array}$ & $1(4.5)$ & $4(16.7)$ & 0.349 \\
\hline $\begin{array}{l}\text { Length of working experience in } \\
\text { infection control }\end{array}$ & $\begin{array}{l}6(4- \\
13.5)\end{array}$ & $7.5(5-15.25)$ & $5(3.25-11.5)$ & 0.192 \\
\hline \multicolumn{5}{|l|}{$\begin{array}{l}\text { Characteristics of medical } \\
\text { institutions }\end{array}$} \\
\hline \multicolumn{5}{|l|}{ Type of hospital } \\
\hline $\begin{array}{l}\text { University-affiliated hospital: } \\
\text { national or public }\end{array}$ & $\begin{array}{l}6 \\
(13.0)\end{array}$ & $0(0)$ & $6(25.0)$ & 0.022 \\
\hline University-affiliated hospital: private & $\begin{array}{l}15 \\
(32.6)\end{array}$ & $12(54.5)$ & $3(12.5)$ & 0.002 \\
\hline $\begin{array}{l}\text { Non-university-affiliated hospital: } \\
\text { national or public }\end{array}$ & $\begin{array}{l}17 \\
(37.0)\end{array}$ & $3(13.6)$ & $14(58.3)$ & 0.002 \\
\hline $\begin{array}{l}\text { Non-university-affiliated hospital: } \\
\text { private }\end{array}$ & $\begin{array}{l}8 \\
(17.4)\end{array}$ & $7(31.8)$ & $1(4.2)$ & 0.020 \\
\hline \multicolumn{5}{|l|}{ Number of hospital beds } \\
\hline Less than 300 & $\begin{array}{l}10 \\
(21.7)\end{array}$ & $3(13.6)$ & $7(29.2)$ & 0.289 \\
\hline $300-599$ & $\begin{array}{l}15 \\
(32.6)\end{array}$ & $10(45.5)$ & $5(20.8)$ & 0.075 \\
\hline
\end{tabular}

Note: Values are presented as median (interquartile range) or number (\%) Abbreviations: COVID-19, coronavirus disease 2019 


\begin{tabular}{|c|c|c|c|c|}
\hline & $\begin{array}{l}\text { Total } \\
(n= \\
46)\end{array}$ & $\begin{array}{l}\text { No. of COVID-19 } \\
\text { cases < } 100 \\
(n=22)\end{array}$ & $\begin{array}{l}\text { No. of COVID-19 } \\
\text { cases } \geq 100 \\
(n=24)\end{array}$ & $\begin{array}{l}P \\
\text { value }\end{array}$ \\
\hline $600-899$ & $\begin{array}{l}11 \\
(23.9)\end{array}$ & $8(36.4)$ & $3(12.5)$ & 0.058 \\
\hline $900-1,199$ & $4(8.7)$ & $0(0)$ & $4(16.7)$ & 0.110 \\
\hline More than 1,200 & $\begin{array}{l}6 \\
(13.0)\end{array}$ & $1(4.5)$ & $5(20.8)$ & 0.190 \\
\hline $\begin{array}{l}\text { Absence of infectious diseases } \\
\text { specialists }\end{array}$ & $\begin{array}{l}10 \\
(21.7)\end{array}$ & $1(4.5)$ & $9(37.5)$ & 0.011 \\
\hline \multicolumn{5}{|c|}{ Note: Values are presented as median (interquartile range) or number (\%) } \\
\hline \multicolumn{5}{|c|}{ Abbreviations: COVID-19, coronavirus disease 2019} \\
\hline
\end{tabular}

\section{Screening and selective treatment policies to prevent COVID-19 patients from entering the hospital}

Table 2 lists the screening and selective treatment policies implemented to prevent COVID-19 patients from entering the hospital. All 46 hospitals operated screening clinics, which treated patients with respiratory symptoms, fever of unknown cause, and epidemiological association with COVID-19 patients, and accepted persons who wanted to undergo polymerase chain reaction (PCR) tests for COVID-19. 
Table 2

Screening and selective treatment policy to prevent COVID-19 patients from entering the hospital

\begin{tabular}{|c|c|c|c|c|}
\hline & $\begin{array}{l}\text { Total } \\
(\mathrm{n}= \\
46)\end{array}$ & $\begin{array}{l}\text { No. of } \\
\text { COVID-19 } \\
\text { cases } \\
<100 \\
(n=22)\end{array}$ & $\begin{array}{l}\text { No. of } \\
\text { CoVID-19 } \\
\text { cases } \\
\geq 100 \\
(n=24)\end{array}$ & $\begin{array}{l}P \text {. } \\
\text { value }\end{array}$ \\
\hline Existence of screening clinic for COVID-19 & $\begin{array}{l}46 \\
(100)\end{array}$ & $22(100)$ & $24(100)$ & - \\
\hline \multicolumn{5}{|l|}{ The criteria of patients treated at the screening clinic ${ }^{1}$} \\
\hline Fever of unknown cause & $\begin{array}{l}45 \\
(97.8)\end{array}$ & $22(100)$ & $23(95.8)$ & 1.000 \\
\hline Respiratory symptoms & $\begin{array}{l}46 \\
(100)\end{array}$ & $22(100)$ & $24(100)$ & - \\
\hline Epidemiological association with COVID-19 patients & $\begin{array}{l}43 \\
(93.5)\end{array}$ & $20(90.9)$ & $23(95.8)$ & 0.600 \\
\hline $\begin{array}{l}\text { Family members had fever, respiratory symptoms or } \\
\text { epidemiological association with COVID- } 19 \text { patients }\end{array}$ & $\begin{array}{l}35 \\
(76.1)\end{array}$ & $17(77.3)$ & $18(75.0)$ & 0.857 \\
\hline Test for COVID-19 voluntarily & $\begin{array}{l}39 \\
(84.8)\end{array}$ & $21(95.5)$ & $18(75.0)$ & 0.098 \\
\hline $\begin{array}{l}\text { Entry into general outpatient clinics was allowed for } \\
\text { patients with fever or respiratory symptoms likely not } \\
\text { associated with COVID-19 }\end{array}$ & $\begin{array}{l}41 \\
(89.1)\end{array}$ & $22(100)$ & $19(79.2)$ & 0.050 \\
\hline No epidemiological association with COVID-19 patients & $\begin{array}{l}11 / 41 \\
(26.8)\end{array}$ & $\begin{array}{l}5 / 22 \\
(22.7)\end{array}$ & $\begin{array}{l}6 / 19 \\
(31.6)\end{array}$ & 0.524 \\
\hline $\begin{array}{l}\text { Healthcare workers at the screening clinic determines } \\
\text { that the possibility of COVID-19 is minimal }\end{array}$ & $\begin{array}{l}24 / 41 \\
(58.5)\end{array}$ & $\begin{array}{l}14 / 22 \\
(63.6)\end{array}$ & $\begin{array}{l}10 / 19 \\
(52.6)\end{array}$ & 0.476 \\
\hline $\begin{array}{l}\text { The patients were negative for COVID-19 testing within } \\
\text { a certain period (e.g. two to three days) }\end{array}$ & $\begin{array}{l}38 / 41 \\
(92.7)\end{array}$ & $\begin{array}{l}22 / 22 \\
(100)\end{array}$ & $\begin{array}{l}16 / 19 \\
(84.2)\end{array}$ & 0.091 \\
\hline $\begin{array}{l}\text { Scheduled follow-up for diseases presenting fever or } \\
\text { respiratory disease }\end{array}$ & $\begin{array}{l}26 / 41 \\
(63.4)\end{array}$ & $\begin{array}{l}13 / 22 \\
(59.1)\end{array}$ & $\begin{array}{l}13 / 19 \\
(68.4)\end{array}$ & 0.536 \\
\hline
\end{tabular}

Note: Values are presented as number (\%)

Abbreviations: COVID-19, coronavirus disease 2019; PCR, polymerase chain reaction

${ }^{1}$ This question requested the respondent to select multiple items

${ }^{2}$ Suspected cases of COVID-19 include fever, respiratory symptoms, and epidemiological associations with COVID-19 patients 


\begin{tabular}{|c|c|c|c|c|}
\hline & $\begin{array}{l}\text { Total } \\
(\mathrm{n}= \\
46)\end{array}$ & $\begin{array}{l}\text { No. of } \\
\text { CoviD-19 } \\
\text { cases } \\
<100 \\
(n=22)\end{array}$ & $\begin{array}{l}\text { No. of } \\
\text { CoviD-19 } \\
\text { cases } \\
\geq 100 \\
(n=24)\end{array}$ & $\begin{array}{l}P \\
\text { value }\end{array}$ \\
\hline $\begin{array}{l}\text { Existence of measures to prevent the influx of COVID-19 } \\
\text { into the hospital through caregivers and } \\
\text { family/acquaintances }{ }^{1}\end{array}$ & $\begin{array}{l}42 \\
(91.3)\end{array}$ & $22(100)$ & $20(83.3)$ & 0.110 \\
\hline $\begin{array}{l}\text { Restrictions on access to general wards by visitors } \\
\text { other than the patient's essential caregivers }\end{array}$ & $\begin{array}{l}38 / 42 \\
(90.5)\end{array}$ & $\begin{array}{l}21 / 22 \\
(95.5)\end{array}$ & $\begin{array}{l}17 / 20 \\
(85.0)\end{array}$ & 0.333 \\
\hline Total restrictions on visits to general wards & $\begin{array}{l}21 / 42 \\
(50.0)\end{array}$ & $\begin{array}{l}9 / 22 \\
(40.9)\end{array}$ & $\begin{array}{l}12 / 20 \\
(60.0)\end{array}$ & 0.217 \\
\hline $\begin{array}{l}\text { Total restrictions on visits to intensive care units and } \\
\text { special wards }\end{array}$ & $\begin{array}{l}28 / 42 \\
(66.7)\end{array}$ & $\begin{array}{l}13 / 22 \\
(59.1)\end{array}$ & $\begin{array}{l}15 / 20 \\
(75.0)\end{array}$ & 0.275 \\
\hline $\begin{array}{l}\text { Regular monitoring of fever and respiratory symptoms } \\
\text { of the caregivers }\end{array}$ & $\begin{array}{l}24 / 42 \\
(57.1)\end{array}$ & $\begin{array}{l}13 / 22 \\
(59.1)\end{array}$ & $\begin{array}{l}11 / 20 \\
(55.0)\end{array}$ & 0.789 \\
\hline Mandatory PCR test for caregivers & $\begin{array}{l}27 / 42 \\
(64.3)\end{array}$ & $\begin{array}{l}17 / 22 \\
(77.3)\end{array}$ & $\begin{array}{l}10 / 20 \\
(50.0)\end{array}$ & 0.065 \\
\hline $\begin{array}{l}\text { Existence of system to pre-screen scheduled patients to } \\
\text { prevent the influx of suspected cases of COVID-191,2 }\end{array}$ & $\begin{array}{l}35 \\
(76.1)\end{array}$ & $19(86.4)$ & $16(66.7)$ & 0.118 \\
\hline $\begin{array}{l}\text { Texts are sent to suspected cases of COVID-19 advising } \\
\text { them to not visit the general outpatient area }\end{array}$ & $\begin{array}{l}28 / 35 \\
(80.0)\end{array}$ & $\begin{array}{l}17 / 19 \\
(89.5)\end{array}$ & $\begin{array}{l}11 / 16 \\
(68.8)\end{array}$ & 0.207 \\
\hline $\begin{array}{l}\text { Self-examinations for suspected cases of COVID- } 19 \text { are } \\
\text { conducted through the internet or mobile before visiting } \\
\text { the hospital }\end{array}$ & $\begin{array}{l}21 / 35 \\
(60.0)\end{array}$ & $\begin{array}{l}13 / 19 \\
(68.4)\end{array}$ & $\begin{array}{l}8 / 16 \\
(50.0)\end{array}$ & 0.268 \\
\hline $\begin{array}{l}\text { Phone call interviews are conducted on suspected } \\
\text { cases of COVID-19 }\end{array}$ & $\begin{array}{l}3 / 35 \\
(8.6)\end{array}$ & $\begin{array}{l}3 / 19 \\
(15.8)\end{array}$ & $0 / 16(0)$ & 0.234 \\
\hline $\begin{array}{l}\text { Management and education concerning wearing masks } \\
\text { for patients and caregivers in the hospital }\end{array}$ & $\begin{array}{l}46 \\
(100)\end{array}$ & $22(100)$ & $24(100)$ & - \\
\hline $\begin{array}{l}\text { Education on wearing masks is provided to patients } \\
\text { and caregivers when hospitalized }\end{array}$ & $\begin{array}{l}33 \\
(71.7)\end{array}$ & $16(72.7)$ & $17(70.8)$ & 0.887 \\
\hline $\begin{array}{l}\text { Banners and postings on wearing masks thoroughly } \\
\text { and properly are placed throughout the institution }\end{array}$ & $\begin{array}{l}41 \\
(89.1)\end{array}$ & $20(90.9)$ & $21(87.5)$ & 1.000 \\
\hline
\end{tabular}

Note: Values are presented as number (\%)

Abbreviations: COVID-19, coronavirus disease 2019; PCR, polymerase chain reaction

${ }^{1}$ This question requested the respondent to select multiple items

${ }^{2}$ Suspected cases of COVID-19 include fever, respiratory symptoms, and epidemiological associations with COVID-19 patients 


\begin{tabular}{|c|c|c|c|c|}
\hline & $\begin{array}{l}\text { Total } \\
(\mathrm{n}= \\
46)\end{array}$ & $\begin{array}{l}\text { No. of } \\
\text { COVID-19 } \\
\text { cases } \\
<100 \\
(n=22)\end{array}$ & $\begin{array}{l}\text { No. of } \\
\text { COVID-19 } \\
\text { cases } \\
\geq 100 \\
(n=24)\end{array}$ & $\begin{array}{l}P \\
\text { value }\end{array}$ \\
\hline $\begin{array}{l}\text { Regular public address announcements on the need for } \\
\text { patients and guardians to wear masks }\end{array}$ & $\begin{array}{l}35 \\
(76.1)\end{array}$ & $20(90.9)$ & $15(62.5)$ & 0.024 \\
\hline $\begin{array}{l}\text { Designated staff monitor patients and guardians and } \\
\text { provide guidance on wearing masks in the hospital }\end{array}$ & $\begin{array}{l}10 \\
(21.7)\end{array}$ & $4(18.2)$ & $6(25.0)$ & 0.725 \\
\hline $\begin{array}{l}\text { Performing PCR tests for non-suspected cases of } \\
\text { COVID-19 }\end{array}$ & $\begin{array}{l}39 \\
(84.8)\end{array}$ & $20(90.9)$ & $19(79.2)$ & 0.418 \\
\hline \multicolumn{5}{|l|}{ The subject of testing } \\
\hline Patients requiring general anesthesia & $\begin{array}{l}19 / 39 \\
(48.7)\end{array}$ & $\begin{array}{l}9 / 20 \\
(45.0)\end{array}$ & $\begin{array}{l}10 / 19 \\
(52.6)\end{array}$ & 0.634 \\
\hline All patients requiring hospitalization & $\begin{array}{l}34 / 39 \\
(87.2)\end{array}$ & $\begin{array}{l}19 / 20 \\
(95.0)\end{array}$ & $\begin{array}{l}15 / 19 \\
(78.9)\end{array}$ & 0.182 \\
\hline $\begin{array}{l}\text { Patients requiring hospitalization in a closed } \\
\text { psychiatric ward }\end{array}$ & $\begin{array}{l}9 / 39 \\
(23.1)\end{array}$ & $\begin{array}{l}3 / 20 \\
(15.0)\end{array}$ & $\begin{array}{l}6 / 19 \\
(31.6)\end{array}$ & 0.273 \\
\hline $\begin{array}{l}\text { Patients who came from a different institution or a } \\
\text { nursing home }\end{array}$ & $\begin{array}{l}16 / 39 \\
(41.0)\end{array}$ & $\begin{array}{l}7 / 20 \\
(35.0)\end{array}$ & $\begin{array}{l}9 / 19 \\
(47.4)\end{array}$ & 0.433 \\
\hline $\begin{array}{l}\text { Patients requiring hospitalization in the intensive care } \\
\text { unit }\end{array}$ & $\begin{array}{l}9 / 39 \\
(23.1)\end{array}$ & $\begin{array}{l}5 / 20 \\
(25.0)\end{array}$ & $\begin{array}{l}4 / 19 \\
(21.1)\end{array}$ & 1.000 \\
\hline \multicolumn{5}{|l|}{ Note: Values are presented as number (\%) } \\
\hline \multicolumn{5}{|c|}{ Abbreviations: COVID-19, coronavirus disease 2019; PCR, polymerase chain reaction } \\
\hline \multicolumn{5}{|c|}{${ }^{1}$ This question requested the respondent to select multiple items } \\
\hline
\end{tabular}

Most hospitals allowed patients with symptoms generally unrelated to COVID-19 to visit the general outpatient clinics; the COVID-19 < 100 group tended to allow such patients more frequently than the COVID-19 $\geq 100$ group $(P=0.050)$. Most hospitals used negative COVID-19 test results within a certain period to determine whether symptomatic patients could enter the general outpatient clinics.

Most hospitals implemented measures to prevent the influx of COVID-19 into the hospital through caregivers and family/acquaintances. Among these hospitals, $90.5 \%$ allowed general ward access only to the patients' essential caregivers, $57.1 \%$ regularly monitored fever and respiratory symptoms of caregivers, and $64.3 \%$ performed mandatory PCR tests for caregivers. 
All medical institutions provided education concerning the use of masks for patients and caregivers, while 35 hospitals made regular public address announcements guiding patients and caregivers to wear masks; these strategies were used more frequently in the COVID-19<100 group $(P=0.024)$. Only 10 hospitals had designated staff who monitored patients and guardians and provided guidance on wearing masks in the hospital. PCR tests were performed even for non-suspected cases of COVID-19 in most hospitals, and most of these hospitals conducted PCR tests for all patients requiring hospitalisation. Additional screening and selective treatment policies for patients with suspected COVID-19 are provided in the Supplementary Table 1.

\section{Preemptive isolation policies for patients with suspected COVID-19}

Table 3 presents the data for preemptive isolation policies for patients with suspected COVID-19. Thirtyfive hospitals implemented preemptive isolation for inpatients with suspected COVID-19, of which 34 released patients from preemptive isolation only after the first negative PCR test after hospitalisation, and two released patients from isolation after 10-14 days of symptom onset or exposure to COVID-19, regardless of the PCR test results. Regarding the criteria for preemptive isolation before confirmation with PCR results, 23/35 hospitals applied preemptive isolation to all patients admitted into the hospital, while 12 hospitals applied preemptive isolation for patients with suspected symptoms of COVID-19, those with imaging results suspected to be pneumonia, and those with an epidemiological association with a COVID-19 patient. Additional isolation policies for patients with suspected or confirmed COVID-19 are provided in the Supplementary Table 1. 
Table 3

Preemptive isolation policy for patients with suspected COVID-19

$\begin{array}{llll}\text { Total } & \begin{array}{l}\text { No. of } \\ \text { CoVID-19 }\end{array} & \begin{array}{l}\text { No. of } \\ \text { CoVID-19 } \\ \text { cases }\end{array} & \begin{array}{l}P \\ \text { value }\end{array} \\ (n= & \begin{array}{l}\text { cases } \\ 35)\end{array} & <100 & \geq 100 \\ & (n=21) & (n=14) & \end{array}$

The healthcare workers who determine preemptive isolation ${ }^{1}$

Preemptive isolation for all patients or patients who meet specific conditions

$\begin{array}{llll}7 & 7(33.3) & 0(0) & 0.027\end{array}$

The doctor who directly treated the patient

26

(74.3)

Healthcare workers belonging to specific

22

departments $^{2}$

(62.9)

$14(66.7)$

$12(85.7)$

0.262

\section{Type of preemptive isolation rooms ${ }^{1}$}

Single isolation room

31

(88.6)

Cohort isolation room

Partly operated as cohort isolation room, and other single rooms

$12(57.1)$

$10(71.4)$

0.392

\section{Criteria for removing the patients from preemptive isolation ${ }^{1}$}

COVID-19 PCR test confirmed negative once

COVID-19 PCR test confirmed negative twice

After 10-14 days of symptom onset, exposure to COVID-19, or suspicion of exposure, regardless of the PCR test results
34

(97.1)

$3(14.3)$

$3(21.4)$

0.664

$6(28.6)$

$2(14.3)$

0.431

$3(14.3) \quad 3(21.4) \quad 0.664$

$18(85.7) \quad 13(92.9)$

0.635

3

$3(14.3)$

$0(0)$

0.259

$2 \quad 0(0)$

$2(14.3)$

0.153

Note: Only hospitals with preemptive isolation policies were included. Values are presented as number $(\%)$

Abbreviations: COVID-19, coronavirus disease 2019; PCR, polymerase chain reaction

${ }^{1}$ This question requested the respondent to select multiple items

2 It includes infectious diseases, pulmonology, and the infection control and prevention office

${ }^{3}$ It includes intensive care units and hematopoietic stem cell transplant wards 


\begin{tabular}{|c|c|c|c|c|}
\hline & $\begin{array}{l}\text { Total } \\
(\mathrm{n}= \\
35)\end{array}$ & $\begin{array}{l}\text { No. of } \\
\text { Covid-19 } \\
\text { cases } \\
<100 \\
(n=21)\end{array}$ & $\begin{array}{l}\text { No. of } \\
\text { COVID-19 } \\
\text { cases } \\
\geq 100 \\
(n=14)\end{array}$ & $\begin{array}{l}P \\
\text { value }\end{array}$ \\
\hline $\begin{array}{l}\text { Determined by healthcare workers belonging to } \\
\text { specific departments }{ }^{2}\end{array}$ & $\begin{array}{l}10 \\
(28.6)\end{array}$ & $5(23.8)$ & $5(35.7)$ & 0.474 \\
\hline \multicolumn{5}{|c|}{$\begin{array}{l}\text { Range of patients put into preemptive isolation before } \\
\text { PCR results are confirmed }\end{array}$} \\
\hline All patients admitted into the hospital & $\begin{array}{l}23 \\
(65.7)\end{array}$ & $15(71.4)$ & $8(57.1)$ & 0.477 \\
\hline Existence of suspected symptoms of COVID-19 & $\begin{array}{l}12 \\
(34.3)\end{array}$ & $6(28.6)$ & $6(42.9)$ & 0.477 \\
\hline $\begin{array}{l}\text { Existence of results of imaging tests that are } \\
\text { suspected to be pneumonia }\end{array}$ & $\begin{array}{l}12 \\
(34.3)\end{array}$ & $6(28.6)$ & $6(42.9)$ & 0.477 \\
\hline $\begin{array}{l}\text { Existence of epidemiological association with a } \\
\text { COVID-19 patient }\end{array}$ & $\begin{array}{l}12 \\
(34.3)\end{array}$ & $6(28.6)$ & $6(42.9)$ & 0.477 \\
\hline Patients being admitted to high-risk wards ${ }^{3}$ & 3 & $2(9.5)$ & $1(7.1)$ & 1.000 \\
\hline $\begin{array}{l}\text { Patients came from a nursing home or were } \\
\text { transferred from a different institution }\end{array}$ & $\begin{array}{l}3 \\
(8.6)\end{array}$ & $1(4.8)$ & $2(14.3)$ & 0.551 \\
\hline \multicolumn{5}{|c|}{$\begin{array}{l}\text { Note: Only hospitals with preemptive isolation policies were included. Values are presented as number } \\
(\%)\end{array}$} \\
\hline \multicolumn{5}{|c|}{ Abbreviations: COVID-19, coronavirus disease 2019; PCR, polymerase chain reaction } \\
\hline \multicolumn{5}{|c|}{${ }^{1}$ This question requested the respondent to select multiple items } \\
\hline \multicolumn{5}{|c|}{2 It includes infectious diseases, pulmonology, and the infection control and prevention office } \\
\hline
\end{tabular}

\section{Policy for COVID-19 patients who showed consistently positive PCR results but whose symptoms had improved and were released from isolation}

Table 4 summarises the policies for COVID-19 patients who showed consistently positive PCR results but also showed improvement in symptoms and were released from isolation. Of the hospitals that 
responded to the survey, 27 treated COVID-19 patients whose PCR results were consistently positive but were released from isolation. As for personal protective equipment (PPE), 17 and 11 hospitals used N95/KF94 masks and surgical masks without using other PPE, respectively. The proportion of usage of surgical masks without other PPE was higher in the COVID-19 $\geq 100$ group $(P=0.010)$. Additional information about PPE for healthcare workers providing care for COVID-19 patients is provided in the Supplementary Table 2. 
Table 4

Policy for patients with COVID-19 whose PCR results are consistently positive but whose symptoms have improved and are released from isolation

\begin{tabular}{|c|c|c|c|c|}
\hline & $\begin{array}{l}\text { Total } \\
(n= \\
27)\end{array}$ & $\begin{array}{l}\text { No. of } \\
\text { COVID-19 } \\
\text { cases }<100 \\
(n=13)\end{array}$ & $\begin{array}{l}\text { No. of } \\
\text { COVID-19 } \\
\text { cases } \geq 100 \\
(n=14)\end{array}$ & $\begin{array}{l}P \\
\text { value }\end{array}$ \\
\hline \multicolumn{5}{|l|}{$\begin{array}{l}\text { Personal protective equipment for the treatment of } \\
\text { the patients }{ }^{1}\end{array}$} \\
\hline Coveralls with PAPR & $0(0)$ & $0(0)$ & $0(0)$ & - \\
\hline Coveralls with N95/KF94 mask & $0(0)$ & $0(0)$ & $0(0)$ & - \\
\hline $\begin{array}{l}\text { N95/KF94 mask + disposable gown + gloves }+ \\
\text { goggles/face shields + hair cover + shoe covers }\end{array}$ & $0(0)$ & $0(0)$ & $0(0)$ & - \\
\hline $\begin{array}{l}\text { N95/KF94 mask + disposable gown + gloves + } \\
\text { goggles/face shields + hair cover }\end{array}$ & $\begin{array}{l}2 \\
(7.4)\end{array}$ & $1(7.7)$ & $1(7.1)$ & 1.000 \\
\hline $\begin{array}{l}\text { N95/KF94 mask + disposable gown + gloves + } \\
\text { goggles/face shields }\end{array}$ & $\begin{array}{l}3 \\
(11.1)\end{array}$ & $3(23.1)$ & $0(0)$ & 0.098 \\
\hline N95/KF94 mask + disposable gown + gloves & $\begin{array}{l}4 \\
(14.8)\end{array}$ & $2(15.4)$ & $2(14.3)$ & 1.000 \\
\hline N95/KF94 mask + gloves & $\begin{array}{l}4 \\
(14.8)\end{array}$ & $2(15.4)$ & $2(14.3)$ & 1.000 \\
\hline N95/KF94 mask & $\begin{array}{l}17 \\
(63.0)\end{array}$ & $7(53.8)$ & $10(71.4)$ & 0.440 \\
\hline Surgical mask & $\begin{array}{l}11 \\
(40.7)\end{array}$ & $2(15.4)$ & $9(64.3)$ & 0.010 \\
\hline \multicolumn{5}{|l|}{ Allocation of hospital room ${ }^{1,2}$} \\
\hline Shared room in a general ward & $\begin{array}{l}20 / 26 \\
(76.9)\end{array}$ & $8(61.5)$ & $12 / 13(92.3)$ & 0.160 \\
\hline $\begin{array}{l}\text { Regardless of the PCR test results (Ct value) or the } \\
\text { time of release from isolation }\end{array}$ & $\begin{array}{l}5 / 26 \\
(19.2)\end{array}$ & $1(7.7)$ & $4 / 13(30.8)$ & 0.322 \\
\hline
\end{tabular}

Note: Only hospitals that had a policy for patients with COVID-19 whose PCR results are consistently positive but whose symptoms have improved and are released from isolation were included. Values are presented as number (\%)

Abbreviations: COVID-19, coronavirus disease 2019; PCR, polymerase chain reaction; $\mathrm{Ct}$, cycle threshold; PAPR, powered air-purifying respirator

${ }^{1}$ This question requested the respondent to select multiple items

2 One hospital wrote a non-categorical answer for the question, and the hospital made a decision after consulting with the infectious diseases specialist 


\begin{tabular}{|c|c|c|c|c|}
\hline & $\begin{array}{l}\text { Total } \\
(n= \\
27)\end{array}$ & $\begin{array}{l}\text { No. of } \\
\text { COVID-19 } \\
\text { cases <100 } \\
(n=13)\end{array}$ & $\begin{array}{l}\text { No. of } \\
\text { COVID-19 } \\
\text { cases } \geq 100 \\
(n=14)\end{array}$ & $\begin{array}{l}P \\
\text { value }\end{array}$ \\
\hline If PCR test results (Ct value) meet certain criteria & $\begin{array}{l}9 / 26 \\
(34.6)\end{array}$ & $5(38.5)$ & $4 / 13(30.8)$ & 1.000 \\
\hline $\begin{array}{l}\text { After a certain period from the time of release } \\
\text { from isolation, regardless of the PCR test results } \\
\text { (Ct value) }\end{array}$ & $\begin{array}{l}7 / 26 \\
(26.9)\end{array}$ & $3(23.1)$ & $4 / 13(30.8)$ & 1.000 \\
\hline $\begin{array}{l}\text { Single room for isolation, without negative } \\
\text { pressure }\end{array}$ & $\begin{array}{l}4 / 26 \\
(15.4)\end{array}$ & $3(23.1)$ & $1 / 13(7.7)$ & 0.593 \\
\hline $\begin{array}{l}\text { Regardless of the PCR test results (Ct value) or the } \\
\text { time of release from isolation }\end{array}$ & $\begin{array}{l}1 / 26 \\
(3.8)\end{array}$ & $0(0)$ & $1 / 13(7.7)$ & 1.000 \\
\hline If PCR test results (Ct value) meet certain criteria & $\begin{array}{l}3 / 26 \\
(11.5)\end{array}$ & $3(23.1)$ & $0 / 13(0)$ & 0.220 \\
\hline $\begin{array}{l}\text { After a certain period from the time of release } \\
\text { from isolation, regardless of the PCR test results } \\
\text { (Ct value) }\end{array}$ & $\begin{array}{l}1 / 26 \\
(3.8)\end{array}$ & $1(7.7)$ & $0 / 13(0)$ & 1.000 \\
\hline Single room for isolation with negative pressure & $\begin{array}{l}2 / 26 \\
(7.7)\end{array}$ & $2(15.4)$ & $0 / 13(0)$ & 0.480 \\
\hline Cohort room for isolation with negative pressure & $\begin{array}{l}0 / 26 \\
(0)\end{array}$ & $0(0)$ & $0 / 13(0)$ & - \\
\hline \multicolumn{5}{|c|}{$\begin{array}{l}\text { Note: Only hospitals that had a policy for patients with COVID-19 whose PCR results are consistently } \\
\text { positive but whose symptoms have improved and are released from isolation were included. Values } \\
\text { are presented as number (\%) }\end{array}$} \\
\hline \multicolumn{5}{|c|}{$\begin{array}{l}\text { Abbreviations: COVID-19, coronavirus disease 2019; PCR, polymerase chain reaction; } \mathrm{Ct} \text {, cycle } \\
\text { threshold; PAPR, powered air-purifying respirator }\end{array}$} \\
\hline \multicolumn{5}{|c|}{${ }^{1}$ This question requested the respondent to select multiple items } \\
\hline
\end{tabular}

Most hospitals (20/26) accommodated such patients in a shared room in a general ward, while 9/26 hospitals allowed shared-room accommodation when the cycle threshold (Ct) value in the PCR test was above a certain threshold, and 7/26 hospitals allowed shared-room accommodation after a certain interval from the time of meeting the national isolation release criteria.

\section{The strategy of procedures or operations for patients with suspected or confirmed COVID-19}


Table 5 shows the strategy of procedures or operations for patients with suspected or confirmed COVID19. Thirty-five responding institutions performed emergency procedures or operations for suspected COVID-19 patients; emergency procedures or operations were performed in a higher proportion of hospitals in the COVID-19 $<100$ group $(P=0.024)$. 
Table 5

The strategy of procedures or operations for patients with suspected or confirmed COVID-19

$\begin{array}{llll}\text { Total } & \begin{array}{l}\text { No. of } \\ \text { COVID- }\end{array} & \begin{array}{l}\text { No. of } \\ \text { COVID- }\end{array} & \begin{array}{l}P \\ \text { value }\end{array} \\ (n= & 19 & 19 & \\ 46) & \text { cases } & \text { cases } \\ & <100 & \geq 100 \\ & (n= & (n=24) \\ & 22) & & \end{array}$

The decision-making process for operations or procedures on patients suspected of COVID-19 in an emergency situation ${ }^{1}$

No operations or procedures are performed for patients suspected of COVID-19
11
(23.9)
$2(9.1)$
$9(37.5)$
0.024

Even in an emergency, all surgeries and procedures are prohibited until a negative PCR result is confirmed

8

(17.4) (27.3)

$2(8.3)$

0.128

Decisions are made by the person in charge of the specific department $^{2}$

$\begin{array}{llll}16 & 9 & 7(29.2) & 0.404 \\ (34.8) & (40.9) & & \end{array}$

Decisions are made by the doctor who is in charge of the patient

12

(26.1) (18.2)

$8(33.3)$

0.242

Decisions are made through the discussion of a consultative committee in the hospital

5

(10.9) (18.2)

Operations and procedures are performed based on the patient confirmed with COVID-19

$1(4.2)$

0.178

Performing emergency procedures or operations on patients suspected of COVID-19

$\begin{array}{llll}35 & 20 & 15 & 0.024 \\ (76.1) & (90.9) & (62.5) & \end{array}$

\section{Elective procedures or operations on patients suspected of COVID-19 requiring preemptive isolation ${ }^{3}$}

All procedures or operations are postponed until the patient is released from preemptive isolation

$29 / 34 \quad 18 / 21$

(85.3) (85.7)

$11 / 13$

(84.6)

$9(37.5) \quad 0.246$

Procedures or operations are performed without delay, wearing personal protective equipment for COVID-19

$5 / 34 \quad 3 / 21$

(14.7) (14.3)

$2 / 13$

(15.4)

Procedures or operations are performed without delay,

$0 / 34 \quad 0 / 21 \quad 0 / 13$

without wearing personal protective equipment for COVID-19

(0)

(0)

(0)

\section{Elective procedures or operations on patients confirmed with} COVID-194

All procedures or operations are postponed until the patient is released from isolation

Procedures or operations are performed without delay, wearing personal protective equipment for COVID-19

$\begin{array}{lll}7 / 33 & 2 / 14 & 5 / 19 \\ (21.2) & (14.3) & (26.3)\end{array}$

0.670 


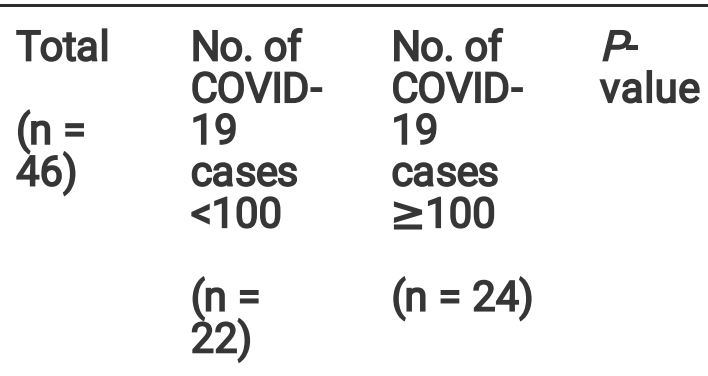

\section{Elective procedures or operations on patients with COVID-19 whose PCR results are consistently positive but whose symptoms have improved and are released from isolation ${ }^{5}$}

\begin{tabular}{|c|c|c|c|c|}
\hline $\begin{array}{l}\text { All procedures or operations are postponed until a negative } \\
\text { PCR result is confirmed }\end{array}$ & $\begin{array}{l}3 / 25 \\
(12.0)\end{array}$ & $\begin{array}{l}2 / 13 \\
(15.4)\end{array}$ & $\begin{array}{l}1 / 12 \\
(8.3)\end{array}$ & 1.000 \\
\hline $\begin{array}{l}\text { Procedures or operations are performed without delay, } \\
\text { wearing personal protective equipment for COVID-19 }\end{array}$ & $\begin{array}{l}1 / 25 \\
(4.0)\end{array}$ & $\begin{array}{l}1 / 13 \\
(7.7)\end{array}$ & $\begin{array}{l}0 / 12 \\
(0)\end{array}$ & 1.000 \\
\hline $\begin{array}{l}\text { Procedures or operations are performed without delay, } \\
\text { without wearing personal protective equipment for COVID-19 }\end{array}$ & $\begin{array}{l}5 / 25 \\
(20.0)\end{array}$ & $\begin{array}{l}1 / 13 \\
(7.7)\end{array}$ & $\begin{array}{l}4 / 12 \\
(33.3)\end{array}$ & 0.160 \\
\hline $\begin{array}{l}\text { Procedures or operations are performed if PCR test results } \\
\text { (Ct value) meet certain criteria }\end{array}$ & $\begin{array}{l}10 / 25 \\
(40.0)\end{array}$ & $\begin{array}{l}6 / 13 \\
(46.2)\end{array}$ & $\begin{array}{l}4 / 12 \\
(33.3)\end{array}$ & 0.688 \\
\hline $\begin{array}{l}\text { Procedures or operations are performed after a certain } \\
\text { period from the time of release from isolation, regardless of } \\
\text { the PCR test results (Ct value) }\end{array}$ & $\begin{array}{l}6 / 25 \\
(24.0)\end{array}$ & $\begin{array}{l}3 / 13 \\
(23.1)\end{array}$ & $\begin{array}{l}3 / 12 \\
(25.0)\end{array}$ & 1.000 \\
\hline
\end{tabular}

Note: Values are presented as number (\%)

Abbreviations: COVID-19, coronavirus disease 2019; PCR, polymerase chain reaction; $\mathrm{Ct}$, cycle threshold

${ }^{1}$ This question requested the respondent to select multiple items

2 It includes infectious diseases, pulmonology, and the infection control and prevention office

311 hospitals that did not have a preemptive isolation policy for patients suspected of COVID-19 and 1 hospital that did not perform elective procedures or operations were excluded

${ }^{4} 7$ hospitals that did not have an isolation policy for patients confirmed with COVID-19 and 6 hospitals that did not perform elective procedures or operations were excluded

519 hospitals that did not have a policy for patients with COVID-19 whose PCR results are consistently positive but whose symptoms have improved and are released from isolation and 2 hospitals that did not perform elective procedures or operations were excluded

As for elective procedures or operations, 29/34 of the hospitals postponed all procedures or operations for suspected COVID-19 patients until the patient was released from preemptive isolation, and 26/33 postponed all procedures or operations for confirmed patients until the isolation was removed. Of the hospitals that treated COVID-19 patients who showed consistently positive PCR results with improvement 
in symptoms and were released from isolation, 10/25 performed procedures or operations when the $\mathrm{Ct}$ value of the PCR test met certain criteria, and $6 / 25$ performed the procedures after a certain interval from the time of release from isolation regardless of the PCR test results.

\section{Hospital work-restriction policy for healthcare workers}

Table 6 presents the data for hospital work-restriction policies for healthcare workers. For healthcare workers who had visited high-risk areas of COVID-19 without fever or respiratory symptoms, 19/44 medical institutions restricted the workers from working and performed PCR tests if they became symptomatic. However, all hospitals restricted healthcare workers with a fever or respiratory symptoms from work and conducted PCR tests. Over $60 \%$ of the participating institutions restricted healthcare workers from performing certain activities outside the hospital. As for the conditions for returning to work among COVID-19 infected employees who met the national isolation release criteria, 14/46 hospitals required COVID-19-infected employees to show negative PCR results before returning to work, and the proportion of such hospitals was higher in the COVID-19 < 100 group. Only 12/46 medical institutions allowed healthcare workers to return to work immediately after meeting the national isolation release criteria. Additional data for decision-making system for COVID-19 related issues is provided in the Supplementary Table 3. 
Table 6

Hospital work restriction policy for healthcare workers

$\begin{array}{llll}\text { Total } & \begin{array}{l}\text { No. of } \\ \text { COVID-19 }\end{array} & \begin{array}{l}\text { No. of } \\ \text { COVID-19 }\end{array} & \begin{array}{l}P \\ \text { value }\end{array} \\ (n= & \begin{array}{l}\text { cases } \\ \text { cases }\end{array} & \\ 46) & <100 & \geq 100 \\ & (n=22) & (n=24) & \end{array}$

Those who have visited high-risk areas of COVID-19, without fever or respiratory symptoms ${ }^{1}$

\begin{tabular}{|c|c|c|c|c|}
\hline Work is restricted for a certain period without PCR test & $\begin{array}{l}5 / 44 \\
(11.4)\end{array}$ & $1 / 22(4.5)$ & $\begin{array}{l}4 / 22 \\
(18.2)\end{array}$ & 0.345 \\
\hline $\begin{array}{l}\text { Work is restricted for a certain period, performing PCR } \\
\text { test }\end{array}$ & $\begin{array}{l}3 / 44 \\
(6.8)\end{array}$ & $1 / 22(4.5)$ & $2 / 22(9.1)$ & 1.000 \\
\hline $\begin{array}{l}\text { Work is restricted until negative PCR results are } \\
\text { confirmed }\end{array}$ & $\begin{array}{l}15 / 44 \\
(34.1)\end{array}$ & $\begin{array}{l}12 / 22 \\
(54.5)\end{array}$ & $\begin{array}{l}3 / 22 \\
(13.6)\end{array}$ & 0.004 \\
\hline $\begin{array}{l}\text { Monitored without PCR test. If they become } \\
\text { symptomatic, a PCR test is conducted, and they are } \\
\text { restricted from work }\end{array}$ & $\begin{array}{l}19 / 44 \\
(43.2)\end{array}$ & $\begin{array}{l}8 / 22 \\
(36.4)\end{array}$ & $\begin{array}{l}11 / 22 \\
(50.0)\end{array}$ & 0.361 \\
\hline
\end{tabular}

\section{Those who have fever or respiratory symptoms}

\begin{tabular}{|c|c|c|c|c|}
\hline Work is restricted for a certain period without PCR tes & $0(0)$ & $0(0)$ & $0(0)$ & - \\
\hline $\begin{array}{l}\text { Work is restricted for a certain period, performing PCR } \\
\text { test }\end{array}$ & $0(0)$ & $0(0)$ & $0(0)$ & - \\
\hline $\begin{array}{l}\text { PCR tests are performed, and work is restricted until } \\
\text { negative results are confirmed }\end{array}$ & $\begin{array}{l}46 \\
(100)\end{array}$ & $22(100)$ & $24(100)$ & - \\
\hline $\begin{array}{l}\text { Existence of restrictions on certain activities outside } \\
\text { the hospital }{ }^{2}\end{array}$ & $\begin{array}{l}29 \\
(63.0)\end{array}$ & $16(72.7)$ & $13(54.2)$ & 0.193 \\
\hline $\begin{array}{l}\text { Prohibition on attending offline conferences or } \\
\text { symposiums }\end{array}$ & $\begin{array}{l}19 / 29 \\
(65.5)\end{array}$ & $\begin{array}{l}11 / 16 \\
(68.8)\end{array}$ & $\begin{array}{l}8 / 13 \\
(61.5)\end{array}$ & 0.714 \\
\hline Prohibition on eating out or attending get-togethers & $\begin{array}{l}20 / 29 \\
(69.0)\end{array}$ & $\begin{array}{l}10 / 16 \\
(62.5)\end{array}$ & $\begin{array}{l}10 / 13 \\
(76.9)\end{array}$ & 0.454 \\
\hline
\end{tabular}

Note: Values are presented as number (\%)

Abbreviations: PCR, polymerase chain reaction; COVID-19, coronavirus disease 2019; Ct, cycle threshold

${ }^{1}$ Two hospitals that did not have a work restriction policy for healthcare workers those who had visited high-risk areas were excluded. Two hospitals wrote non-categorical answers for the question. One hospital monitored the employees after performing PCR tests without work restriction, and another hospital made a decision in the infection control office.

${ }^{2}$ This question requested the respondent to select multiple items 


\begin{tabular}{|c|c|c|c|c|}
\hline & $\begin{array}{l}\text { Total } \\
(\mathrm{n}= \\
46)\end{array}$ & $\begin{array}{l}\text { No. of } \\
\text { COVID-19 } \\
\text { cases } \\
<100 \\
(n=22)\end{array}$ & $\begin{array}{l}\text { No. of } \\
\text { COVID-19 } \\
\text { cases } \\
\geq 100 \\
(n=24)\end{array}$ & $\begin{array}{l}P \\
\text { value }\end{array}$ \\
\hline Prohibition on travelling overseas & $\begin{array}{l}26 / 29 \\
(89.7)\end{array}$ & $\begin{array}{l}15 / 16 \\
(93.8)\end{array}$ & $\begin{array}{l}11 / 13 \\
(84.6)\end{array}$ & 0.573 \\
\hline Prohibition on using multi-use facilities & $\begin{array}{l}17 / 29 \\
(58.6)\end{array}$ & $\begin{array}{l}9 / 16 \\
(56.3)\end{array}$ & $\begin{array}{l}8 / 13 \\
(61.5)\end{array}$ & 0.774 \\
\hline Prohibition on using public transport & $\begin{array}{l}0 / 29 \\
(0)\end{array}$ & $0 / 16(0)$ & $0 / 13(0)$ & - \\
\hline Prohibition on visiting other regions & $\begin{array}{l}3 / 29 \\
(10.3)\end{array}$ & $\begin{array}{l}2 / 16 \\
(12.5)\end{array}$ & $1 / 13(7.7)$ & 1.000 \\
\hline \multicolumn{5}{|l|}{$\begin{array}{l}\text { The conditions for returning to work among COVID-19 } \\
\text { infected employees after national isolation release } \\
\text { criteria has been met }\end{array}$} \\
\hline $\begin{array}{l}\text { Immediately after meeting national isolation release } \\
\text { criteria }\end{array}$ & $\begin{array}{l}12 \\
(26.1)\end{array}$ & $2(9.1)$ & $10(41.7)$ & 0.012 \\
\hline $\begin{array}{l}\text { After a certain period following release from isolation, } \\
\text { regardless of PCR test results }\end{array}$ & $\begin{array}{l}9 \\
(19.6)\end{array}$ & $4(18.2)$ & $5(20.8)$ & 1.000 \\
\hline The PCR test results (Ct value) meet certain criteria & $\begin{array}{l}11 \\
(23.9)\end{array}$ & $6(27.3)$ & $5(20.8)$ & 0.609 \\
\hline After confirming negative PCR results & $\begin{array}{l}14 \\
(30.4)\end{array}$ & $10(45.5)$ & $4(16.7)$ & 0.034 \\
\hline \multicolumn{5}{|l|}{ Note: Values are presented as number (\%) } \\
\hline \multicolumn{5}{|c|}{$\begin{array}{l}\text { Abbreviations: PCR, polymerase chain reaction; COVID-19, coronavirus disease 2019; Ct, cycle } \\
\text { threshold }\end{array}$} \\
\hline \multicolumn{5}{|c|}{$\begin{array}{l}1 \text { Two hospitals that did not have a work restriction policy for healthcare workers those who had } \\
\text { visited high-risk areas were excluded. Two hospitals wrote non-categorical answers for the question. } \\
\text { One hospital monitored the employees after performing PCR tests without work restriction, and } \\
\text { another hospital made a decision in the infection control office. }\end{array}$} \\
\hline
\end{tabular}

\section{Discussion}

This study investigated the measures taken by medical institutions to prevent the spread of COVID-19 in the Republic of Korea. Through the study, we could identify real-world strategies for controversial areas since no clear guidelines have been established. 
All hospitals operated screening clinics, and nearly $90 \%$ allowed patients with symptoms not considered to be associated with COVID-19 to enter their general outpatient clinics. Because screening clinics are equipped with minimal facilities and a workforce that can only provide a minimal examination [7], most hospitals manage patients with fever and respiratory symptoms who are unlikely to have COVID-19 at the general outpatient clinic, where careful evaluation and management can be provided. Unfortunately, there are no clear criteria for the entry of symptomatic patients in general outpatient clinics, which can lead to confusion among frontline medical professionals [5]. As observed in this study, many hospitals implemented efficient strategies for patient selection that can be benchmarked by other hospitals, including (i) negative COVID-19 test results within two to three days, (ii) previously treated in general outpatient clinics for a disease related to the current symptoms, and (iii) minimal probability of COVID-19 as determined by experts.

The proportion of asymptomatic patients among COVID-19 cases was about $20-30 \%$, and viral shedding can occur from such patients [8-10]. Because of concerns regarding the transmission of COVID-19 by asymptomatic patients, CDC recommended PCR tests for screening of COVID-19 even for hospitalised patients without COVID-19-related symptoms [11]. A study conducted in long-term care facilities in the United States showed that the prevalence of COVID-19 in facilities that performed broad preemptive PCR tests on inpatients was $0.5 \%$, while it was $28.0 \%$ in facilities that did not perform them [12]. Nevertheless, approximately $15 \%$ of the hospitals in this study did not perform PCR tests on patients without fever or respiratory symptoms. Although this strategy seems to be effective for detecting asymptomatic COVID-19 patients, its cost-effectiveness remains unproven. Thus, considering the local COVID-19 prevalence, it is necessary to determine whether to proceed with PCR tests when asymptomatic patients are hospitalised [13]. According to the Infectious Diseases Society of America (IDSA), screening asymptomatic patients is expected to be effective in regions with more than $2 \%$ prevalence, considering the results of missing a COVID-19 diagnosis and the sensitivity of PCR tests [14]. However, based on the strategy used by many of the hospitals in this study, screening PCR tests for selected patients such as those requiring general anaesthesia, those admitted to the intensive care unit, and those transferred from other medical institutions and nursing homes can be considered in communities with a low prevalence of COVID-19. Furthermore, considering the ongoing COVID-19 vaccination programme in the country and the $95 \%$ efficacy of the messenger ribonucleic acid (mRNA) vaccine, limiting PCR tests to unvaccinated patients or caregivers with unclear COVID-19-related symptoms can be a viable option [15].

Three-quarters of the hospitals in the present study implemented preemptive isolation for suspected COVID-19 patients, and most hospitals applied a negative COVID-19 PCR test result as the criterion for release from preemptive isolation. In a single-centre study in South Korea, 350 patients with suspected COVID-19 on the basis of symptoms and epidemiological associations with COVID-19 patients were preemptively isolated, and none of them were confirmed to have COVID-19 [16]. Thus, preemptive isolation for inpatients showing no clear epidemiological association with COVID-19 patients could be considered only in the presence of suspected COVID-19 symptoms or pneumonia in imaging examinations. Since the mean latent period of COVID-19 is 5.2 days after exposure to SARS-CoV-2, even 
though most hospitals discontinued preemptive isolation after a single negative PCR test result, a second PCR test should be considered for patients with a strong suspicion of COVID-19 [13, 17-19].

Although the probability of infectious SARS-CoV-2 is very low after 10 days from the onset of COVID-19 symptoms in most cases, severely ill or immunocompromised patients can transmit infectious virus particles even after 10 days [18, 20-23], and the continuing possibility of COVID-19 transmission from these hospitalised patients, especially those who need aerosol-generating procedures, has been a topic of concern $[22,24-26]$. For these reasons, only $19 \%$ of the hospitals treated these patients in a shared room in a general ward regardless of the PCR test results or the time of release from isolation in this survey. Since $50 \%$ of patients show positive results in real-time polymerase chain reaction (RT-PCR) tests of nasopharyngeal swabs at around 18 days after the onset of symptoms, and some patients show a positive result even eight weeks later, the inclusion of negative PCR test results in the criteria for release from isolation is likely to lead to unnecessary isolation and excessive use of PPE [26, 27]. Since the cutoff values for quantitative RT-PCR and quantitative immunoassays tend to be correlated with the infectivity of COVID-19, some researchers have suggested that certain cut-off values could be used as surrogate markers for the decision to release hospitalised patients from isolation $[22,28,29]$.

Although the current guidelines include many recommendations on PPE for healthcare workers, clear guidelines for the management of healthcare workers were not available. As a result, work-restriction policies for healthcare workers differed across hospitals. Since medical personnel can also spread COVID-19 to other people in medical institutions, many hospitals applied stricter return-to-work criteria than the national guidelines for healthcare workers infected with or exposed to COVID-19. However, strict criteria for returning to work could result in a lack of a sufficient workforce [30]. Thus, the implementation of suitable criteria considering the specificity of the hospitals' situations is essential.

This study had some potential limitations. First, the survey was conducted in February 2021, and the situation may have changed by the time the results are presented. Second, this survey was performed only in South Korea, and since the prevalence of and social response to COVID-19 differs among countries, additional investigations might be required in other regions or countries. Nevertheless, the findings remain significant since they highlight the importance of appropriate guidelines and indicate key topics relevant to real hospital settings for further research based on the results of this study.

\section{Conclusions}

In conclusion, because of the lack of clear guidance on infection-control strategies for preventing COVID19 transmission within hospitals, individual hospitals are currently relying on experience to frame relevant guidelines. Thus, systematic research on these areas and guidance at the national level is needed for greater consistency and standardisation in hospitals' measures to prevent COVID-19 outbreaks.

\section{List Of Abbreviations}


COVID-19, Coronavirus disease 19; SARS-CoV-2, severe acute respiratory syndrome coronavirus 2; WHO, World Health Organization; ID, infectious diseases; CDC, Centers for Disease Control and Prevention; ECDC, European Centre for Disease Prevention and Control; KDCA, Korea Disease Control and Prevention Agency; PCR, polymerase chain reaction; PPE, personal protective equipment; $\mathrm{Ct}$, cycle threshold; IDSA, Infectious Diseases Society of America; mRNA, messenger ribonucleic acid; RT-PCR, real-time polymerase chain reaction

\section{Declarations}

\section{Ethics approval and consent to participate:}

The study protocol was approved by the Institutional Review Board of the Seoul National University Bundang Hospital (B-2101/660-303). Online written informed consent was obtained from the participants.

\section{Consent for publication:}

Not applicable.

\section{Availability of data and materials:}

All data generated or analysed during this study are included in this published article and its supplementary information files.

\section{Competing interests:}

The authors declare that they have no competing interests.

\section{Funding:}

This work was supported under the framework of the international cooperation program managed by the National Research Foundation of Korea (2020K2A9A1A0109507911). The funders had no role in the study design, data collection and analysis, preparation of the manuscript, or the decision to publish.

\section{Authors' contributions:}

Conceptualization: Kim B, Kim ES, Song KH, Kim HB. Data curation: Jang W, Kim B. Formal analysis: Jang W, Kim B. Funding acquisition: Kim HB. Investigation: Jang W, Kim B. Methodology: Jang W, Kim B, Kim ES, Song KH, Kim HB. Project administration: Kim B, Kim ES, Song KH, Kim HB. Resources: Kim B, Kim ES, Song KH, Moon SM, Lee MJ, Park JY, Kim JY, Shin MJ, Lee H, Kim HB. Software: Jang W, Kim B. Supervision: Kim HB. Validation: Kim B, Kim ES, Song KH, Kim HB. Visualization: Jang W, Kim B. Writing original draft: Jang W. Writing - review \& editing: Kim B.

\section{Acknowledgements:}


We would like to thank the infection-control team for their participation and Kurt B. Stevenson for his inestimable and generous contribution. We would also like to thank the centre for public healthcare policy of the national medical centre for providing the contact information for the infection-control team.

\section{References}

1. World Health Organization (WHO). COVID-19 - China: Disease outbreak news, https://www.who.int/emergencies/disease-outbreak-news/item/2020-DON229;updated 2020.

2. World Health Organization (WHO). Coronavirus disease 2019 (COVID-19): Situation Report, https://www.who.int/publications/m/item/situation-report--51, vol. 51;updated 2020.

3. Abbas M, Robalo Nunes T, Martischang R, et al. Nosocomial transmission and outbreaks of coronavirus disease 2019: The need to protect both patients and healthcare workers. Antimicrob Resist Infect Control 2021;10(1):7. doi: 10.1186/s13756-020-00875-7.

4. Guo W, Li M, Dong Y, et al. Diabetes is a risk factor for the progression and prognosis of COVID-19. Diabetes Metab Res Rev 2020:e3319. doi: 10.1002/dmrr.3319.

5. Jang W, Kim B, Kim ES, et al. Are the current guidelines sufficient to establish infection control strategies for COVID-19 related issues in hospitals? J Korean Med Sci 2021;36(50):e343. doi: 10.3346/jkms.2021.36.e343.

6. An JA, Song KH, Kim ES, et al. Pandemic preparedness of an academic medical centre in the Republic of Korea. Clin Microbiol Infect 2020;26(12):1595-9. doi: 10.1016/j.cmi.2020.08.032.

7. Kim JE, Lee JH, Lee H, et al. COVID-19 screening center models in South Korea. J Public Health Policy 2021;42(1):15-26. doi: 10.1057/s41271-020-00258-7.

8. Buitrago-Garcia D, Egli-Gany D, Counotte MJ, et al. Occurrence and transmission potential of asymptomatic and presymptomatic SARS-CoV-2 infections: A living systematic review and metaanalysis. PLOS Med 2020;17(9):e1003346. doi: 10.1371/journal.pmed.1003346.

9. Bai Y, Yao L, Wei T, et al. Presumed asymptomatic carrier transmission of COVID-19. JAMA 2020;323(14):1406-7. doi: 10.1001/jama.2020.2565.

10. Kim SE, Jeong HS, Yu Y, et al. Viral kinetics of SARS-CoV-2 in asymptomatic carriers and presymptomatic patients. Int J Infect Dis 2020;95:441-3. doi: 10.1016/j.ijid.2020.04.083.

11. Centers for Disease Control and Prevention (CDC). Testing strategies for SARS-CoV-2, https://www.cdc.gov/coronavirus/2019-ncov/lab/resources/sars-cov2-testingstrategies.html;updated 2021.

12. Telford CT, Onwubiko U, Holland DP, et al. Preventing COVID-19 outbreaks in long-term care facilities through preemptive testing of residents and staff members - Fulton County, Georgia, March-May 2020. MMWR Morb Mortal Wkly Rep 2020;69(37):1296-9. doi: 10.15585/mmwr.mm6937a4.

13. Jung J, Kim J, Lim JS, et al. Pitfall of universal pre-admission screening for SARS-CoV-2 in a low prevalence country. Viruses 2021;13(5):804. doi: 10.3390/v13050804. 
14. Hanson KE, Caliendo AM, Arias CA, et al. Infectious Diseases Society of America Guidelines on the Diagnosis of COVID-19: Molecular Diagnostic Testing. Infectious Diseases Society of America;2020; version 2.0.0, https://www.idsociety.org/practice-guideline/covid-19-guideline-diagnostics/.

15. Polack FP, Thomas SJ, Kitchin N, et al. Safety and efficacy of the BNT162b2 mRNA Covid-19 vaccine. N Engl J Med 2020;383(27):2603-15. doi: 10.1056/NEJMoa2034577.

16. Shi HJ, Lee JB, Choi MK, et al. Protection and response of a tertiary hospital in South Korea to the COVID-19 outbreak. Disaster Med Public Health Prep 2021;15(1):e1-e5. doi: 10.1017/dmp.2020.199.

17. World Health Organization (WHO). Criteria for releasing COVID-19 patients from isolation: Scientific brief, https://apps.who.int/iris/handle/10665/332451;updated 2020.

18. Centers for Disease Control and Prevention (CDC). Ending isolation and precautions for people with COVID-19: Interim guidance, https://www.cdc.gov/coronavirus/2019-ncov/hcp/durationisolation.html;updated 2021.

19. Xin H, Li Y, Wu P, et al. Estimating the latent period of coronavirus disease 2019 (COVID-19). Clin Infect Dis 2021:ciab746. doi: 10.1093/cid/ciab746.

20. Cheng HY, Jian SW, Liu DP, et al. Contact tracing assessment of COVID-19 transmission dynamics in Taiwan and risk at different exposure periods before and after symptom onset. JAMA Intern Med 2020;180(9):1156-63. doi: 10.1001/jamainternmed.2020.2020.

21. Wölfel R, Corman VM, Guggemos W, et al. Virological assessment of hospitalized patients with COVID-2019. Nature 2020;581(7809):465-9. doi: 10.1038/s41586-020-2196-x.

22. Bullard J, Dust $K$, Funk $D$, et al. Predicting infectious severe acute respiratory syndrome coronavirus 2 from diagnostic samples. Clin Infect Dis 2020;71(10):2663-6. doi: 10.1093/cid/ciaa638.

23. Arons MM, Hatfield KM, Reddy SC, et al. Presymptomatic SARS-CoV-2 infections and transmission in a skilled nursing facility. N Engl J Med 2020;382(22):2081-90. doi: 10.1056/NEJMoa2008457.

24. Liu WD, Chang SY, Wang JT, et al. Prolonged virus shedding even after seroconversion in a patient with COVID-19. J Infect 2020;81(2):318-56. doi: 10.1016/j.jinf.2020.03.063.

25. Korea Centers for Disease Control \& Prevention Division of Risk Assessment and International Cooperation. Findings from investigation and analysis of re-positive cases, https://www.kdca.go.kr/board/board.es?mid=a30402000000\&bid=0030;updated 2020.

26. National Center for Infectious Diseases. Chapter of infectious disease physicians of the Academy of Medicine of Singapore. Period of infectivity to inform strategies for de-isolation for COVID-19 patients, https://www.ams.edu.sg/view-pdf.aspx?

file=media\%5c5556_fi_331.pdf\&ofile=Period+of+Infectivity+Position+Statement+(final)+23-5-20+ (logos).pdf;updated 2020.

27. Woodruff A. COVID-19 follow up testing. J Infect 2020;81(4):647-79. doi: 10.1016/j.jinf.2020.05.012.

28. La Scola B, Le Bideau M, Andreani J, et al. Viral RNA load as determined by cell culture as a management tool for discharge of SARS-CoV-2 patients from infectious disease wards. Eur $\mathrm{J}$ Clin Microbiol Infect Dis 2020;39(6):1059-61. doi: 10.1007/s10096-020-03913-9. 
29. Krupp K, Madhivanan P, Perez-Velez CM. Should qualitative RT-PCR be used to determine release from isolation of COVID-19 patients? J Infect 2020;81(3):452-82. doi: 10.1016/j.jinf.2020.06.030.

30. Jo HJ, Kim JS, Choe PG, et al. Work restrictions for healthcare personnel with potential in-hospital exposure to SARS-CoV-2: Experience at a tertiary hospital. J Korean Med Sci 2021;36(38):e274. doi: 10.3346/jkms.2021.36.e274.

\section{Supplementary Files}

This is a list of supplementary files associated with this preprint. Click to download.

- Supplement12.docx

- Supplement3Questionnaireconsistedofopenquestions.docx

- Supplement4Questionnaireconsistedofclosedquestions.docx

- SupplementaryFigure.pptx

- SupplementaryTables.docx 